\title{
Husbandry Practices of Dairy Farming at Chittagong Sub-urban Area
}

\author{
Faruk MSA ${ }^{1 *}$, Islam SKMA ${ }^{1}$, Alam $\mathrm{M}^{2}$, Deb A ${ }^{3}$ and Chanda $\mathrm{GC}^{4}$ \\ ${ }^{l}$ Department of Physiology, Biochemistry and Pharmacology; ${ }^{2}$ Department of Animal Science and Nutrition; \\ Faculty of Veterinary Medicine, Chittagong Veterinary and Animal Sciences University, Khulshi, Chittagong- \\ 4225, Bangladesh \\ ${ }^{3}$ Department of Youth Development and Research, Chittagong- 4216, Bangladesh. \\ ${ }^{4}$ Department of Dairy and Poultry Science, Faculty of Veterinary Medicine, Chittagong Veterinary and Animal \\ Sciences University, Khulshi, Chittagong-4225, Bangladesh
}

[Received: November 19, 2015; Accepted: December 08, 2015]

\begin{abstract}
The present study was carried out to know the present status including general information, feeding, breeding, housing, milking etc. and costs and returns of small dairy farms, to compare the productive and reproductive performance of crossbred and indigenous cows and to make recommendation for development of small scales dairy farming. With this view, the empirical data were collected by using pretested questionnaire. The study was conducted at preselected 30 dairy farms in Chittagong suburban area, and four months-long survey was diminished on thirty small dairy owners. It appeared that $57 \%$ farm owners belong to business class and remaining $43 \%$ to different categories. Fifty three percent took dairying as a side-business whereas only $47 \%$ took it as a main business enterprise. Major percentage of farm owner education level was Higher Secondary $(60 \%)$. The dry period, calving interval, services per conception and day's open of crossbred was $98.5 \pm 18.9,419 \pm 11,3.1 \pm 0.82,118 \pm 25.8$ and indigenous was $140 \pm 10.4,428 \pm 24.7,1.95 \pm 0.44,137 \pm 7.78$ respectively. The study showed that there were significant $(\mathrm{P}<0.01)$ differences within the dry period, services per conception, calving to first service, highest and lowest milk production and lactation period of crossbred and indigenous dairy cows. The study also showed non-significant differences within calving interval for crossbred and indigenous. In case of small dairy farming, the farms were facing a lot of problems such as scarcity of feeds and fodder, high price of concentrate and lack of technical knowledge. This type of dairy farming will be a potential sector for economic development of Bangladesh.
\end{abstract}

Key words: Cost and return, crossbred, dairy farming, indigenous, performance.

\section{INTRODUCTION}

The economy of Bangladesh is mainly based on Agriculture. Livestock plays a crucial role in the agricultural economy. About $36 \%$ of the total animal protein comes from the livestock products in our everyday life. In our countries $25 \%$ peoples are directly engaged in livestock sector and 50\% peoples are partly associated in livestock production. Last year, the contribution of livestock sub-sector to the GDP was $2.51 \%$, which was estimated about $7-8 \%$ GDP to agriculture [1]. That's why the dairy farm is raising day by day all over the Bangladesh. Development of dairy has generated considerable employment through the production and marketing of dairy and dairy products [2]. The majority of the dairy cattle are in the hands of smallholder dairy producers. Also dairying is part of the mixed farming systems in Bangladesh [3] and a predominant source of income, nutrition and jobs [4, 5]. Dairying is also considered a strong tool to develop a village micro economy of Bangladesh [6] in order to improve rural livelihoods and to alleviate rural poverty. Potentially, therefore, small-scale dairying is a viable tool to spur economic growth and alleviate poverty and malnutrition. Chittagong is now in a very satisfactory position on dairy farming contrast. More or less, majority farms are in beneficial condition and contribute in national economy. The husbandry practices of these farms are vital issue. For determination the actual condition of this dairy farm various parameters like housing, feeding, breeding, biosecurity \& health care management that mean the overall husbandry status need to evaluate.

\section{MATERIALS AND METHODS}

\section{Study area and time}

The study was conducted at Chittagong district in Bangladesh between September to December, 2013. Its geographical location is $22^{\circ} 21^{\prime} 49^{\prime \prime} \mathrm{N}$ and $91^{\circ} 48^{\prime}$ 12 " E in DMS (Degrees Minutes Seconds).

\section{Sources and methods of data collection}

In order to collect the more purified data of various farms an organized questionnaire was formatted [7, 8]. Data were collected through face to face interviewing of farmer and personal visits to the randomly selected dairy farming households involved in small scale dairy farming. A questionnaire was designed to capture information related to general characteristics of the household and the household head; farmland ownership and use housing pattern; production, inputs, costs and profits/income from dairy farming and other households activities; income from non-farm activities; expenditure of income from dairy farming; 
assets ownership; perceived benefits and constraints to dairy farming [9].

\section{Sampling methods}

Chittagong district and Patiya upazila were selected in bias (Non-random selection). Patiya upazila have 22 unions. From these union five unions were randomly selected and from this five unions six farm was selected randomly (Multi-stage random sampling). The farms which have $3 \leq$ cattle as define as small scale dairy farm are our target population.

\section{Population and sample size}

All the dairy farms of the district engaged in production were classified as population of the study. On the basis of-nature of research and analysis; number of variables; resource constraints; and, the importance of decision, a sample size of 30 Dairy farms were selected.

\section{Data Analysis}

After collecting all the data of individual dairy farms, we analyze some vital husbandry issues like housing, feeding, breeding, udder health status, biosecurity condition etc. Here we tried to make a comparative deviation on these key issues from a minimum standard that required for a dairy farm operation. Actually percentage (\%) of some special important husbandry practice is find out here and graphically represent on some contrast. The obtained data was stored in Excel-2007 and imported to software STATA/IC-11.0 (STATA Corporation, USA) for analysis. Stored data were tabulated and arranged as percent value. Descriptive statistics (i.e. means, frequencies etc) was done to estimate the different variables. Unpaired unequal t-test was used to determine the level of significance $(\mathrm{P}<0.01)$ between categorical variables.

\section{RESULTS AND DISCUSSION}

General information of small dairy farm owners The general information of selected dairy farm owners in Chittagong sub-urban areas are presented in Table 1. The results showed that the highest percentage $(57 \%)$ of the farmers had business as the principal occupation and the rest job seekers, agriculture. It was observed that $53 \%$ of the farmers had taken dairying as a main business and the rest as side business. Highest percentage $(60 \%)$ of the farmers had higher secondary level education and nobody was found illiterate and under secondary education level. This result were not agree with Uddin et al. [9] who reported that highest percentage $(65 \%)$ of the farm householders had higher primary level of education followed by secondary level education (17.5\%). Hossain et al [10] stated that the average literacy rate of farm households in all farm categories was more than $60 \%$ which had above primary level of education. Similar observations have also been reported by Mollel et al. [11]. Kabir [12] conducted an economic study and found that the average literacy rate of farm households in all farm categories was also sufficiently higher than the national average. More than $76 \%$ house numbers of family in all the farm categories had above primary level of education. The crossbred farm owners had relatively higher level of education. Farmers were further categorized based on land owner. The highest percentage (57\%) of farmers posses 1-2 acres of land and lowest percentage (7\%) of farmers posses $0.5-1$ acres of land. It was found that $16.7 \%$ farmers had training on dairy farms and $83.3 \%$ farms had no training on dairy farm management. This result is contraindicated with Sriri et al [13] but agree with Hossain et al [12] who reported that $18 \%$ farmers had training on dairy farms and $81 \%$ farms had no training on dairy farm management. For establishing dairy farms, $7 \%$ of dairy farmers were dependent on bank loan, $10 \%$ on their own sources and $83 \%$ on bank loan and own source. The average capital investment was Tk. 45,000 to 2,50,000.

\section{Housing management}

Only $10 \%$ of the farmers provide half building and rest $90 \%$ of the farmers used tin shed and straw shed to house their cattle (Table 2). Highest percentage of farmers $(80 \%)$ provided open house, $13 \%$ provided closed and rest used semi-closed house. This result opposes the findings of Uddin et al [9] who reported that highest percentage of farmers $(77.5 \%)$ provided open house, $22.5 \%$ provided closed and semi-closed house. In another region of the same district, Hossain et al [14] observed that $63 \%$ farmers provided closed house and $63 \%$ farmers used paved floor.

\section{Feeding management}

There were two systems of feeding, which were practiced by the dairy owners to feed their cattle. $63 \%$ farmers followed stall feeding and $37 \%$ farmers followed both stall and grazing system (Table 2). All calves were fed milk by suckling. No farmers were found using bottle to provide milk to calves. The main livestock feed at the study area was rice straw. Most of the farmers $(80 \%)$ used untreated straw. It was noted that $20 \%$ and $40 \%$ farmers cultivated napier and maize, respectively and rest of the farmers did not cultivate fodder. Most important constraints regarding fodder cultivation are scarcity of land, scarcity of seed/cutting and lack of knowledge.

\section{Breeding system}

It was observed that $87 \%$ cows were inseminated artificially and $13 \%$ both naturally and artificially (Table 2) which is similar to the observation by Hossain et al [14] who found 93\% cows were inseminated artificially. For artificial insemination, the majority of the farmers preferred Friesian semen.

\section{Overall management system}

It was observed that $100 \%$ farmers milked their cows manually. Most of the farmers (77\%) used traditional equipments and $53 \%$ farmers milked their cows hygienically (Table 2). The source of water in most of the farms was direct water supply by local authority and the supply was adequate in $80 \%$ farms. Majority of the farmers cleaned their cattle house 
regularly with the help of pipe. The same findings were also revealed in a study by Urassa and Raphael [15] in Tanzania.

\section{Productive and reproductive parameters of}

The average length of calving interval of crossbred and indigenous cows stood at 419 and 428 days, respectively (Table 3). Statistically non-significant variations existed between the length of calving interval between crossbred and indigenous cows.

Table 1: General information of farm owners (N: 30)

\begin{tabular}{|c|c|c|}
\hline Varibles & No. of Farms & Percentage $(\%)$ \\
\hline \multicolumn{3}{|l|}{ Owner's Occupation } \\
\hline Service holder & 2 & 7 \\
\hline Business & 17 & 57 \\
\hline Job seeker & 5 & 17 \\
\hline Agriculture & 3 & 10 \\
\hline Others & 3 & 9 \\
\hline \multicolumn{3}{|l|}{ Dairy Farming } \\
\hline Main business & 14 & 47 \\
\hline Side business & 16 & 53 \\
\hline \multicolumn{3}{|l|}{ Education } \\
\hline Class 6-10 & 3 & 10 \\
\hline Secondary school level & 5 & 17 \\
\hline Higher school level & 18 & 60 \\
\hline Above higher secondary level & 4 & 13 \\
\hline \multicolumn{3}{|l|}{ Land Size (acre) } \\
\hline $0-0.5$ & 2 & 7 \\
\hline $0.5-1.0$ & 5 & 17 \\
\hline $1-2$ & 17 & 57 \\
\hline $2-5$ & 4 & 13 \\
\hline Above 5 & 2 & 7 \\
\hline \multicolumn{3}{|l|}{ Source of fund } \\
\hline Bank loan & 2 & 7 \\
\hline Own source & 3 & 10 \\
\hline Both & 25 & 83 \\
\hline \multicolumn{3}{|l|}{ Herd size (Number) } \\
\hline $0-3$ & 2 & 7 \\
\hline $4-8$ & 9 & 30 \\
\hline $9-15$ & 14 & 47 \\
\hline $16-30$ & 4 & 13 \\
\hline Above 30 & 1 & 3 \\
\hline \multicolumn{3}{|l|}{$\begin{array}{l}\text { Monthly income } \\
\text { (Thousand ) }\end{array}$} \\
\hline $0-2$ & 6 & 20 \\
\hline $2-4$ & 14 & 47 \\
\hline $4-6$ & 4 & 13 \\
\hline Above & 6 & 20 \\
\hline
\end{tabular}

\section{crossbred and indigenous cows}

\section{Dry period}

The average dry period for crossbred and indigenous cows was 98.5 and 140 days respectively (Table 3). There was a statistically significant variation $(\mathrm{P}<0.01)$ in the length of dry period of crossbred and indigenous cows. These results were in agreement with Ali et al. [16] and Nahar et al. [17] Ali et al. [16] observed that average dry period for crossbred and indigenous cows were 97.2 and 141 days, respectively. Nahar et al. [17] found that the average dry period for F1 graded Sindhi and Sahiwal as 146 and 127 days, respectively.

\section{Calving interval}

Nahar [18] found that under urban conditions, the mean calving interval of Sindhi and Sahiwal cows were 415 and 429 days, respectively. Ali et al. [16] stated that average length of calving interval of crossbred and indigenous were 653 and 539 days, respectively which contradict to this study.

\section{Service per conception}

The average services per conception of crossbred and indigenous cows were 3.10 and 1.95 , respectively (Table 3), which were significantly different $(\mathrm{P}<0.01)$. These results were in agreement with Ali et al. [16] who reported that the service per conception of crossbred and indigenous cows were 3.33 and 1.98, respectively in Chittagong district.

\section{Calving to first service}


Table 3 shows that the average calving to first service for crossbred and indigenous were 118 and 137 days, respectively, which were significantly different $(\mathrm{P}<0.01)$. This result were in agreement with the information of Ali et al. [16] who observed that average calving to first service for crossbred and indigenous were 124 and 114 days, respectively.
The difference in milk production between crossbred and indigenous cows was highly significant $(\mathrm{P}<0.01)$. Similar studies were made by Halim [19] who found that total milk production per lactation of crossbred and indigenous cows were 800 and 296 litres, respectively.

Table 2: Housing system, feeding system, fodder cultivation, breeding system and overall management system $(\mathrm{N}=30)$

\begin{tabular}{|c|c|c|c|c|}
\hline Information & & Percentage & Information & Percentage \\
\hline Housing & Type of cow shed & & Washing of udder by & \\
\hline \multirow[t]{7}{*}{ system } & Half building & 10 & Warm water & 43 \\
\hline & Tin shed & 40 & Normal water & 87 \\
\hline & Straw shed & 50 & Daily equipment & \\
\hline & Pattern of housing & & Traditional & 77 \\
\hline & Open & 80 & Modern & - \\
\hline & closed & 13 & Semi-modern & 23 \\
\hline & Semi closed & 7 & Preventive register & \\
\hline Feeding & Types of feeding & & Maintained & 7 \\
\hline \multirow[t]{10}{*}{ System } & system & & Not maintained & 93 \\
\hline & Stall & 63 & Storage of milk & \\
\hline & Stall + Grazing & 37 & Freezing & 17 \\
\hline & Grazing & - & Not stored & 83 \\
\hline & Others & - & Isolation of sick & \\
\hline & Type of calf & & cattle & 7 \\
\hline & handling & & Kept isolated & \\
\hline & Sucking & 100 & Not kept isolated & 93 \\
\hline & Bottling & - & Causes of disposal & \\
\hline & Milk starter & - & Unproductive & 30 \\
\hline Fodder & Type of grasses & & Infertility & 70 \\
\hline \multirow[t]{6}{*}{ cultivation } & Napier & 20 & Labor type & \\
\hline & Maize & 40 & Skilled & 7 \\
\hline & No grass cultivation & 40 & Non skilled & 93 \\
\hline & Type of roughage & & Place of selling & \\
\hline & Treated & 20 & Broker & 17 \\
\hline & Untreated & 80 & Local market & 13 \\
\hline Breeding & Breeding method & & Sweet market & 20 \\
\hline \multirow[t]{3}{*}{ system } & AI & 87 & Home service & 20 \\
\hline & AI and natural & 13 & Own selling center & 30 \\
\hline & Natural & - & Disposal of manure & \\
\hline Overall & Milking & & Sold out & 73 \\
\hline manageme & Hygienically & 53 & As manure & 20 \\
\hline \multirow[t]{12}{*}{ nt system } & Unhygienically & 47 & As fuel & 7 \\
\hline & Cleaning & & Sanitizer used & \\
\hline & Regularly & 72 & Phenyl & 70 \\
\hline & Irregularly & 28 & Potas & 23 \\
\hline & Water source & & Phenyl + Potas & 50 \\
\hline & Water supply & 77 & Bleeching powder & 30 \\
\hline & Tube well & 13 & Treatment by & \\
\hline & pond & 10 & Veterinary surgeon & 90 \\
\hline & Water supply & & Locally trained person & 10 \\
\hline & Adequate & 80 & Cleaning done by & \\
\hline & Inadequate & 20 & Pipe & 77 \\
\hline & & & bucket & 23 \\
\hline
\end{tabular}

\section{Highest and lowest milk production}

It was revealed from table 3 , the highest milk production from crossbred and indigenous cows were 10.4 and 2.40 litres/day, respectively, and lowest milk production 2.29 and 0.72 litres/day, respectively.

\section{Milk yield per lactation}

Milk yield per lactation for crossbred and indigenous were 1210 and 358 litres, respectively.
The average lactation period tor crossbred and indigenous cows was 283 and 207 days, respectively, which differ significantly $(\mathrm{P}<0.01)$. Another study made by Halim [19] who found the length of lactation period for crossbred and indigenous cows were 259 and 228 days, respectively.

Milking management

Table 3 : Productive and reproductive performances of dairy cows

\begin{tabular}{lllc}
\hline Parameters & Crossbred & Indigenous & Level of significance \\
\hline Dry period (days) & $98.5 \pm 18.9$ & $140 \pm 10.4$ & $* *$ \\
Calving interval (days) & $419 \pm 11$ & $428 \pm 24.7$ & $\mathrm{NS}$ \\
Service per conception & $3.10 \pm 0.82$ & $1.95 \pm 0.44$ & $* *$ \\
Calving to first service (days) & $118 \pm 25.8$ & $137 \pm 7.78$ & $* *$ \\
Highest milk production (lt/day) & $10.4 \pm 1.79$ & $2.40 \pm 0.51$ & $* *$ \\
Lowest milk production (lt/day) & $2.92 \pm 0.72$ & $0.72 \pm 0.25$ & $* *$ \\
Milk yield (lt/lactation) & $1210 \pm 57.8$ & $358 \pm 27.1$ & $* *$ \\
Lactation period (days) & $283 \pm 14.5$ & $207 \pm 13.7$ & $* *$ \\
Average milk $\quad$ production & $4.27 \pm 0.52$ & $1.78 \pm 0.13$ & $* *$ \\
(Lt/lactation) & & & \\
\hline
\end{tabular}

$* *=$ Significance at $1 \%$ level of probability. NS=Non significant. 
All of the farmers were using calves for milk letdown (100\%). Majority of the animals were milked by females through folded thumb. Only $70 \%$ respondents were washing the teat / udder of animals before milking (Table 4). On overall basis, farmers
Bilal et al [20] who pointed out that milk letdown with the help of calves, milking by folded thumb, nonwashing of teat udder prior to milking are the predisposing factors responsible for high incidence of mastitis under field conditions.

Table 4: Adoption trend of feeding, milking and health management related practices at farmer's level $(\mathrm{N}=30)$.

\begin{tabular}{|c|c|c|}
\hline Practices & Respondents & Frequency $(\%)$ \\
\hline $\begin{array}{l}\text { Awareness about high yielding fodder } \\
\text { variety }\end{array}$ & 4 & 13.33 \\
\hline Use of rice polish as concentrate & 30 & 100 \\
\hline Silage making & 1 & 3.33 \\
\hline Urea treated straw & 7 & 23.33 \\
\hline Urea molasses block & 0 & 0 \\
\hline $\begin{array}{l}\text { Source of milk letdown } \\
\text { i) Calf sucking } \\
\text { ii) Oxytocin injection } \\
\text { iii) Concentrate feeding }\end{array}$ & $\begin{array}{c}30 \\
0 \\
0\end{array}$ & $\begin{array}{c}100 \\
0 \\
0\end{array}$ \\
\hline $\begin{array}{l}\text { Milking by } \\
\text { i) Male } \\
\text { ii) Female }\end{array}$ & $\begin{array}{l}12 \\
18\end{array}$ & $\begin{array}{l}40 \\
60\end{array}$ \\
\hline $\begin{array}{l}\text { Milking method } \\
\text { i) Full hand } \\
\text { ii) Folded thumb } \\
\text { iii) Mechanical }\end{array}$ & $\begin{array}{c}7 \\
23 \\
0\end{array}$ & $\begin{array}{c}23.33 \\
76.67 \\
0\end{array}$ \\
\hline $\begin{array}{l}\text { Udder/teat washing } \\
\text { i) Yes } \\
\text { ii) No }\end{array}$ & $\begin{array}{c}21 \\
9\end{array}$ & $\begin{array}{l}70 \\
30\end{array}$ \\
\hline $\begin{array}{l}\text { Vaccination against hemorrhagic septicemia } \\
\text { i) Yes } \\
\text { ii) No }\end{array}$ & $\begin{array}{l}11 \\
19\end{array}$ & $\begin{array}{l}36.67 \\
63.33\end{array}$ \\
\hline $\begin{array}{l}\text { Vaccination against foot and mouth disease } \\
\text { i) Yes } \\
\text { ii) No }\end{array}$ & $\begin{array}{l}18 \\
12\end{array}$ & $\begin{array}{l}60 \\
40\end{array}$ \\
\hline $\begin{array}{l}\text { Deworming } \\
\text { i) Yes } \\
\text { ii) No }\end{array}$ & $\begin{array}{c}23 \\
7\end{array}$ & $\begin{array}{l}76.67 \\
23.33\end{array}$ \\
\hline $\begin{array}{l}\text { Dipping } \\
\text { i) Yes } \\
\text { ii) No }\end{array}$ & $\begin{array}{c}9 \\
21\end{array}$ & $\begin{array}{l}30 \\
70\end{array}$ \\
\hline $\begin{array}{l}\text { Control of parasites } \\
\text { i) Yes } \\
\text { ii) no }\end{array}$ & $\begin{array}{l}13 \\
17\end{array}$ & $\begin{array}{l}43.33 \\
56.67\end{array}$ \\
\hline Mastitis detection and teat dipping & 0 & 0 \\
\hline
\end{tabular}

were highly ignorant about the recommended milking management practices. There was a general response from the respondents that mastitis is the common problem in lactating animals. This might be attributed to frequent injury/ wound on teats due to calf's teeth, skin flora opportunist, and use of milk foam. These survey findings are in line with those of

\section{Health management}

Respondents were paying little attention towards the health management of dairy animals. The vaccination against hemorrhagic septicemia and foot and mouth diseases was being done by $36.67 \%$ and $60 \%$ farm respectively and only $43.33 \%$ were taking measures to control parasites. There was a common 
complaint from the farmers that every year so many animals die due to hemorrhagic septicemia even though these animals had been vaccination. The probable reason may be the use of low quality vaccine and use of a small dose than recommended Yaqub et al [21] pointed out that hemorrhagic septicemia and foot and mouth diseases are the major problems under field conditions and in time vaccination with recommended dose is the only successful preventive measure. Javed and Ahamd [22] reported that parasites are responsible for huge economic losses under field conditions. This might be due to climate factors, poor husbandry practices and lack of knowledge on the part of livestock farmers.

\section{CONCLUSION}

Bangladesh is considered one of the most suitable countries in the world for dairy farming. The present management condition of small dairy farms in Patiya at Chittagong district is more or less traditional and the productive and reproductive performance of crossbred cows was better than that of indigenous cows. Most of the farmers believe that dairy farming is a profitable enterprise and can be more profitable if Government gives support on feed cost, marketing, loan and management training.

\section{REFERENCES}

1. DLS. 2013. Department of Livestock Services, Bangladesh, Organization's detail.

2. Nedelea A, Grosu V and Shamsuddoha M (2009). Dairy Farming-an Alternative Income Generating Activity. Bulletin UASVM Horticulture. 66(2): 352-355.

3. Saadullah M (2001). Smallholder Dairy Production and Marketing in Bangladesh, Paper presented at South-South Workshop on Smallholder Dairy Production and Marketing, NDDB-ILBS, March. 2001, Ahmedabad, India, 13-16.

4. Miyan HA (1996). Towards sustainable development: The national conservation strategy of Bangladesh, Consultancy report on the livestock sector. Ministry of Environment and Forestry, Dhaka, Bangladesh.

5. Haque SAM (2009). Bangladesh: Social gains from dairy development. In: Animal Production and Health Commission for Asia and the Pacific and Food and Agriculture Organization (APHCA-FAO) publication on smallholder dairy development: Lessons learned in Asia, RAP publication 2009/2.

6. Shamsuddin M, Alam MM, Hossein M S, Goodger WJ, Bari FY, Ahmed TU, Hossain MM and Khan AHMSI (2007). Participatory rural appraisal to identify needs and prospects of market-oriented dairy industries in Bangladesh. Trop. Anim. Health Prod. 39:567-581.
7. Nauta WJ, Baars T, Groen AF, Veerkamp RF and Roep D (2001). Animal Breeding in Organic Farming, Discussion paper, Louis Bolk Institute, Driebergen.

8. De Jong H and Van Soest Y (2001). De biologische melkveehouderijsector in kaart gebracht, Productschap Zuivel, Rijswijk.

9. Uddin MN, Uddin MB, Mamun M, Hassan MM and Khan MMH (2012). Small Scale Dairy Farming for Livelihoods of Rural Farmers: Constraint and Prospect in Bangladesh. J. Anim. Sci. Adv. 2(6): 543550 .

10. Hossain MM, Alam MM, Rashid MM, Asaduzzaman M and Rahman MM (2005). Small Scale Dairy Farming Practice in a Selective Area of Bangladesh. Pak. J. Nutr. 4 (4): 215-221.

11. Mollel EL, Lekule FP, Kurwijila RL, Turuka FM and Petersen PH (1999). A Socioeconomic study on the role of gender in small scale crop-livestock farming in Turiani, Morogoro. Proceedings of the $26^{\text {th }}$ Scientific Conference LITI-TENGERU Arusha, TSAP conferences series. 26: 354-360.

12. Kabir MA 1995. An economic study of subsidized private dairy farming in selected area of Bangladesh, M.Sc. Thesis Department of Agricultural Economic, Bangladesh Agricultural University, Mymensingh, Bangladesh, pp: 129-134.

13. Sriri MT, Jaouhari ME, Saydi A, Kuper M and Gal PY (2011). Supporting small-scale dairy farmers in increasing milk production: evidence from Morocco. Trop. Anim. Health Prod. 43:41-49.

14. Hossain ZMA, Hossain SMJ, Rashid MM, Sultana N and Ali MH (2004). Study on the present management condition of private dairy farm at Rangpur Sadar Thana in Bangladesh. J. Biol. Sci. 3.

15. Urassa JK and Raphael E (2002). The contribution of small scale dairy farming to community welfare: a case study of Morogoro Municipality. http://www.fiuc.org/esap/MOROG/MOROG5 /General/dairyfarming.pdf

16. Ali MH, Khan MAS, Islam MN, Khan MKI, Rashid MM and Khatun MJ (2000). Comparative performance study on the crossbreeds and indigenous cows under small holder dairy farming. Pak. J. Biol. Sciences. 3: 795-798.

17. Nahar TN, Islam M and Hasnath MA (1992). A comparative study on the performance of F1 crossbred cows under rural conditions. AsianAustralian Journal of Animal Sciences, 5: 435-438.

18. Nahar N (1987). A comparative study on the performances of $\mathrm{F} 1$ crossbred progenies on Farm an Urban conditions, M.Sc. Thesis, Department of Animal Breeding and Genetics. 
Bangladesh Agricultural University, Mymensingh.

19. Halim MA (1992). A comparative economic analysis of local and crossbred dairy cows in a selected area of Dhaka district. M.Sc. Thesis, Department of Agricultural Economics, Bangladesh Agricultural University, Mymensingh, Bangladesh, 10-23.

20. Bilal MO, Iqbal MU, Muhammad G, Avais M and Sajid MS (2004). Factors affecting the prevalence of clinical mastitis in buffaloes around Faisalabad district (Pakistan). Inter. J. Agril. Biol. 6(1): 185-187.
21. Yaqub T, Ahmad R and Ahmad A (1997). Isolation and characterization of Past. multocida from suspected cases of HS. $18^{\text {th }}$ Annual Report. LPRI Bahadurnagar, OkaraPakistan.

22. Javed S and Ahmad R (1988). Identification of endoparasites in buffalo and cattle at livestock experiment station, Bahadurnagar, Oadirabad and around Bahadurnagar Farm. $9^{\text {th }}$ Annual Report, LPRI Bahadurnagar, OkaraPakistan. 